\title{
Effect of calcium on phenothiazine inhibition of neutrophil degranulation
}

\author{
R. Alexander Blackwood and Ronald J. Hessler \\ Department of Pediatrics, Division of Infectious Diseases, University of Michigan Medical Center, Ann Arbor, Michigan
}

\begin{abstract}
The phenothiazines are known to be potent inhibitors of calmodulin and have been used as probes for examining calmodulin-dependent cellular functions. We report here that the characteristics of phenothiazine inhibition of exocytosis in neutrophils more closely resemble their interaction with the annexins in vitro. $\mathrm{Ca}^{2+}$. dependent aggregation of liposomes mediated by either annexin I or annexin II was inhibited by the phenothiazines. Inhibition of liposome aggregation was not caused by interference with the binding of annexins to phospholipids. Rather, the phenothiazines increased the concentration of $\mathrm{Ca}^{2+}$ required for aggregation. Likewise, in neutrophils permeabilized with streptolysin $O$, inhibition of degranulation by phenothiaxines could be overcome by increasing $\left[\mathrm{Ca}^{2+}\right]$. These results suggest that inhibition by phenothiazines of neutrophil degranulation is secondary to the ability of these compounds to inhibit membrane-membrane contact promoted by the annexins. $J$. Leukoc. Biol. 58: 114-118; 1995.
\end{abstract}

Key Wonds: exocytosis $\cdot$ secretion $\cdot$ trifluoperazine $\cdot$ annexins

\section{INTRODUCTION}

The annexins are a family of $\mathrm{Ca}^{2+}$-dependent, phospholipid binding proteins that share a common structural motif. They each contain at least four repeats of a 70 amino acid sequence [1]. Although the function of the annexins remains unclear, their ability to bind to phospholipids in the presence of $\mathrm{Ca}^{2+}$ suggests that they mediate the membrane fusion that occurs during exocytosis [2, 3]. In support of this hypothesis, annexin I (lipocortin I), annexin II (calpactin I), and annexin VII (synexin) [4-9] have been found capable of promoting the aggregation and fusion of phospholipid vesicles in $\mathrm{C} \mathrm{Ca}^{2+}$-dependent manner. In addition, annexin II reconstitutes exocytosis in adrenal chromaffin cells permeabilized with digitonin $[10,11]$.

The phenothiazines are a class of antipsychotic drugs that include trifluoperazine, chlorpromazine, and promethazine. They are known to bind to calmodulin in a $\mathrm{Ca}^{2+}$-dependent manner, inhibiting calmodulin's regulatory activity. Because of their assumed specificity, the phenothiazines have been used as probes to study a variety of calmodulin-dependent cellular functions. They inhibit exocytosis in a number of different cell types, including neutrophils $[12,13]$ and adrenal chromaffin cells [14]. In addition, the phenothiazines inhibit synexinmediated aggregation, as well as fusion of adrenal chromaffin granules [14] and neutrophil-specific granules [12].

We examined the relationship between $\left[\mathrm{Ca}^{2+}\right]$ and inhi- bition by phenothiazines of annexin-mediated liposome aggregation. We report here that phenothiazines do not inhibit binding of annexins to phospholipid vesicles. However, they shift the $\mathrm{Ca}^{2+}$-dependent aggregation curve to the right. A similar effect was observed in neutrophils that had been permeabilized with streptolysin $O$ and then stimulated with increasing concentrations of $\mathrm{Ca}^{2+}$.

\section{MATERIALS AND METHODS}

Phospholipids were obtained from Avanti Polar Lipids (Birmingham, $\mathrm{AL}$ ). $\mathrm{CaCl}_{2}$ hydrate ( $>99.99 \%$ pure) was obtained from Aldrich Chemical Co. (Milwaukee, WI). EGTA (puriss grade, >99\%) was obtained from Fluka Chemical Co. (Ronkonkoma, NY). Calmodulin was obtained from Calbiochem-Novabiochem Co. (San Diego, CA). Anticalmodulin antibody was obtained from Upstate Biotechnology Inc. (Lake Placid, NY). High-performance liquid chromatography grade $\mathrm{H}_{2} \mathrm{O}$ was obtained from Fischer Scientific (Pittsburgh, PA). All other chemicals were obtained from Sigma Chemical Co. (St. Louis, MO).

Phenothiazine stock solutions were made fresh daily at a concentration of $500 \mathrm{mM}$ in DMSO. Serial dilutions in buffer A $(50 \mathrm{mM}$ HEPES, $100 \mathrm{mM} \mathrm{KCl}, 1 \mathrm{mM}$ EGTA, pH 7.0) or buffer B (50 mM HEPES, 100 $\mathrm{mM} \mathrm{KCl}, 20 \mathrm{mM} \mathrm{NaCl}, 2 \mathrm{mM} \mathrm{MgCl}_{2}, 1 \mathrm{mM}$ EGTA, $0.1 \%$ dextrose, $\mathrm{pH}$ 7.0) were prepared for binding and aggregation assays or for experiments with permeabilized cells, respectively. The final concentration of DMSO was $<0.04 \%(v / v)$.

Stock solutions of streptolysin $O$ in high-performance liquid chromatography grade $\mathrm{H}_{2} \mathrm{O}(25,000 \mathrm{U} / \mathrm{ml})$ were prepared daily. Streptolysin $\mathrm{O}$ was activated with $8 \mathrm{mM}$ dithiothreitol in buffer $B$ for $10 \mathrm{~min}$ at $37^{\circ} \mathrm{C}$. Final concentrations of streptolysin $O$ and dithiothreitol in buffer $B$ were $75 \mathrm{U} / \mathrm{ml}$ and $0.1 \mathrm{mM}$, respectively.

Annexin I and annexin II were purified from human placenta and bovine lung by using a modification of the method of Haigler et al. [15], as described previously [16]. $\mathrm{Ca}^{2+}$ stock solutions were prepared in either buffer $A$ or buffer $B$ by using the system of Bers [17], as described previously [4]. The $\left[\mathrm{Ca}^{2+}\right]$ of a 1:4 dilution of each stock solution was measured with a $\mathrm{Ca}^{2+}$-sensitive electrode (Orion Research, Inc., Boston, MA.). The $\left[\mathrm{Ca}^{2+}\right]$ of the final dilutions ranged between 0.44 and $450 \mu \mathrm{M}$.

Liposomes were prepared by hydrating $4 \mathrm{mg}$ of phosphatidylserine (PS; previously dried from chloroform solution under $\mathrm{N}_{2}$ ) with $0.5 \mathrm{ml}$ of buffer $A$. The suspensions were vortexed and sonicated twice. To select liposomes that pellet readily under the conditions of the binding assay, pellets were collected from three rounds of centrifugation at $13,000 \mathrm{~g}$. Final pellets were suspended in $250 \mu \mathrm{l}$ of buffer A. Binding assays were performed as previously described by using approximately $250 \mu \mathrm{mol}$ PS [4].

Aggregation assays were performed as described previously [4]. Briefly, liposomes and $\mathrm{Ca}^{2+}$ stock solution (final dilution 1:4) were adjusted with buffer $A$ to yield an absorbance at $450 \mathrm{~nm}$ between 0.6 and 0.7 (approximately $500 \mathrm{nmol}$ of PS) with the desired concentration of phenothiazine in a final volume of $0.8 \mathrm{ml}$. After a 2-min equilibration, either annexin I or II was added (140 nM final concentration) and

Abbreviations: PS, phosphatidylserine; LDH, lactate dehydrogenase. Reprint requests: $\mathbf{R}$. Alexander Blackwood, University of Michigan Medical Center, 107 Simpson Drive, Room 1114, Ann Arbor, MI 48109 0244.

Received August 29, 1995; accepted March 31, 1995. 
absorbance at $450 \mathrm{~nm}$ was monitored continuously for $5 \mathrm{~min}$

Human neutrophils were obtained from fresh venous blood and isolated by using the method of Boyum [18]. Briefly, blood from healthy donors was collected by using citrate phosphate adenine as an anticoagulant. After centrifugation at $150 \times g$ to remove platelets, cells were separated on a $10 \%$ Ficoll-Hypaque cushion followed by sedimentation in $6 \%$ dextran. Contaminating red blood cells were removed by hypo tonic lysis. The resulting cells (98\% neutrophils) were washed three times in phosphate-buffered saline then counted and suspended in buffer B that had been prewarmed to $37^{\circ} \mathrm{C}$. All buffers used subsequently were prewarmed and all incubations were conducted at $37^{\circ} \mathrm{C}$ unless otherwise stated. After a $10-\mathrm{min}$ incubation, neutrophils $\left(1 \times 10^{7}\right.$ cells $/ \mathrm{ml}$ ) were incubated with $75 \mathrm{U} / \mathrm{ml}$ streptolysin $O$ for an additional $10 \mathrm{~min}$. The cells were centrifuged at $750 \times \mathrm{g}\left(4^{\circ} \mathrm{C}\right)$ for $5 \mathrm{~min}$ and the supernatants were removed for measurements of lactate dehydrogenase (LDH) [19] and $\beta$-glucuronidase [20] activities. The cell pellets were resuspended in buffer $B\left(2 \times 10^{7}\right.$ cells $\left./ \mathrm{ml}\right)$ and $250-\mu l$ aliquots $\left(5 \times 10^{6}\right.$ cells) were added to $125 \mu$ l buffer B containing varying concentrations of trifluoperazine. Cells were incubated for $5 \mathrm{~min}$ before adding $125 \mu$ of a $\mathrm{Ca}^{2+}$ stock solution (prepared in buffer $\mathrm{B}$ ). We chose $45 \mu \mathrm{M} \mathrm{Ca}{ }^{2+}$ because it was the lowest (closest to physiological) concentration of $\mathrm{Ca}^{2+}$ that gave consistent significant detectable release of $\boldsymbol{\beta}$-glucuronidase activity from permeabilized cells in control experiments. The cells were incubated for an additional $15 \mathrm{~min}$ at $37^{\circ} \mathrm{C}$ and then pelleted at $1500 \times$ $g\left(5 \mathrm{~min}\right.$ at $\left.4^{\circ} \mathrm{C}\right)$. Supernatants were recentrifuged at $13,000 \times g\left(4^{\circ} \mathrm{C}\right.$ for $20 \mathrm{~min}$ ) and assayed for $\beta$-glucuronidase activity.
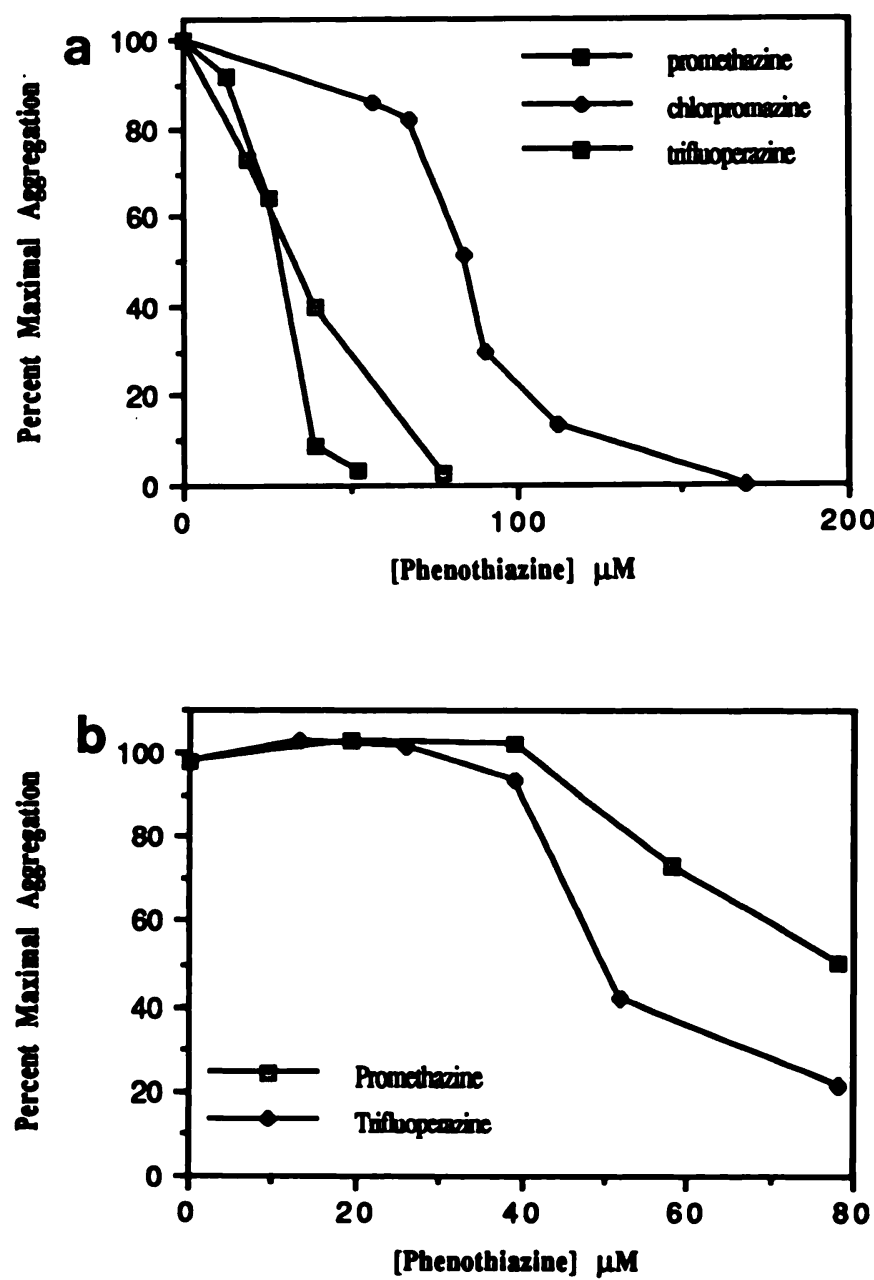

Fig. 1. Phenothiazines inhibit the aggregation of liposomes mediated by the annexins. Varying concentrations of phenothiazines (promethazine, chlorpromazine, or trifluoperazine), liposomes, and $\mathrm{Ca}^{2+}$ were combined in a cuvette. Aggregation was monitored spectrophotometerically by the change in absorbance $\left(\mathrm{OD}_{450}\right)$ after the addition of annexin I or II (140 nM). (a) Annexin I, trifluoperazine, and promethazine at $10 \mu \mathrm{M} \mathrm{Ca}^{2+}$ and chlorpromazine at $6 \mu \mathrm{M} \mathrm{Ca}^{2+}$. (b) Annexin II at $10 \mu \mathrm{M} \mathrm{Ca}^{2+}$. The data are representative of two to three independent experiments.

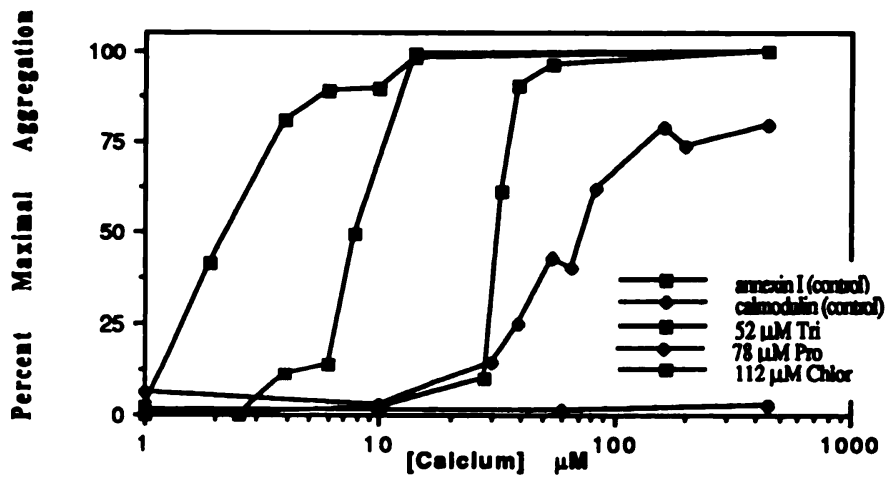

Fig. 2. Phenothiazines shift the $\mathrm{Ca}^{2+}$-dependent, annexin-mediated aggregation curves to the right. Experiments were performed in an identical manner with those in Figure 1 with the exception that phenothiazine concentrations were kept constant while the $\mathrm{Ca}^{2+}$ concentration was varied. The dose for each phenothiazine was chosen such that more than $80 \%$ inhibition of aggregation occurred at $6 \mu \mathrm{M} \mathrm{Ca}{ }^{2+}$. For calmodulin control, aggregation was initiated with $140 \mathrm{nM}$ calmodulin instead of annexin I. Similar results were achieved with annexin II. The data are representative of two to three independent experiments.

\section{RESULTS}

\section{Inhibition by phenothiazines of liposome aggregation}

The phenothiazines are known to be potent inhibitors of polymorphonuclear leukocyte degranulation. Because one of the early steps in the membrane-membrane fusing events observed during degranulation is the apposition of the two fusing partners, which in vitro can be modeled by examining phospholipid vesicle aggregation, we examined the effect of three of the phenothiazines on annexinmediated phospholipid vesicle aggregation. In control experiments aggregation was $\mathrm{Ca}^{2+}$ and annexin dependent. No aggregation of liposomes was observed in the absence of added protein at $\mathrm{Ca}^{2+}$ concentrations up to 1 $\mathrm{mM}$, nor did annexin I or II promote aggregation in the absence of $\mathrm{Ca}^{2+}$. For comparison, aggregation data were expressed relative to a standard condition, i.e., the change in absorbance observed after $5 \mathrm{~min}$ when annexin I (140 $\mathrm{nM}$ ) was incubated with liposomes in the presence of $450 \mu \mathrm{M} \mathrm{Ca}^{2+}$.

All three of the phenothiazines examined (trifluoperazine, promethazine, and chlorpromazine) exhibited a concentration-dependent inhibition of the aggregation of liposomes mediated by the annexins (Fig. 1). In the presence of $10 \mu \mathrm{M} \mathrm{Ca}^{2+}$ the phenothiazine concentration at which $50 \%$ inhibition of annexin-mediated aggregation occurred ( $\left.\mathrm{ID}_{50}\right)$ ranged between 20 and $100 \mu \mathrm{M}$. Interestingly, inhibition was inversely related to the $\left[\mathrm{Ca}^{2+}\right]$ (Fig. 2). Increasing $\left[\mathrm{Ca}^{2+}\right]$ overcame the inhibitory effects of a given concentration of phenothiazine.

\section{Effects of phenothiazines on binding of annexins to phospholipid}

Both annexin I and annexin II bound to and co-sedimented with PS liposomes in the presence of less than 10 $\mu \mathrm{M}$ free $\mathrm{Ca}^{2+}$. None of the phenothiazines, at concentrations up to $312 \mu \mathrm{M}$, inhibited the binding of the annexins to PS liposomes (Fig. 3). No sedimentation of annexins occurred in control reaction mixtures containing phenothiazines, but lacking either $\mathrm{Ca}^{2+}$ or phospholipid, demonstrated that phenothiazine-annexin aggregation was 


\section{$1 \mathrm{mM}$ EGTA $6 \mu \mathrm{M} \mathrm{Ca}^{2+}$

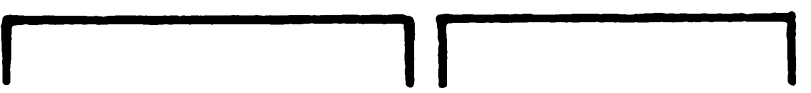

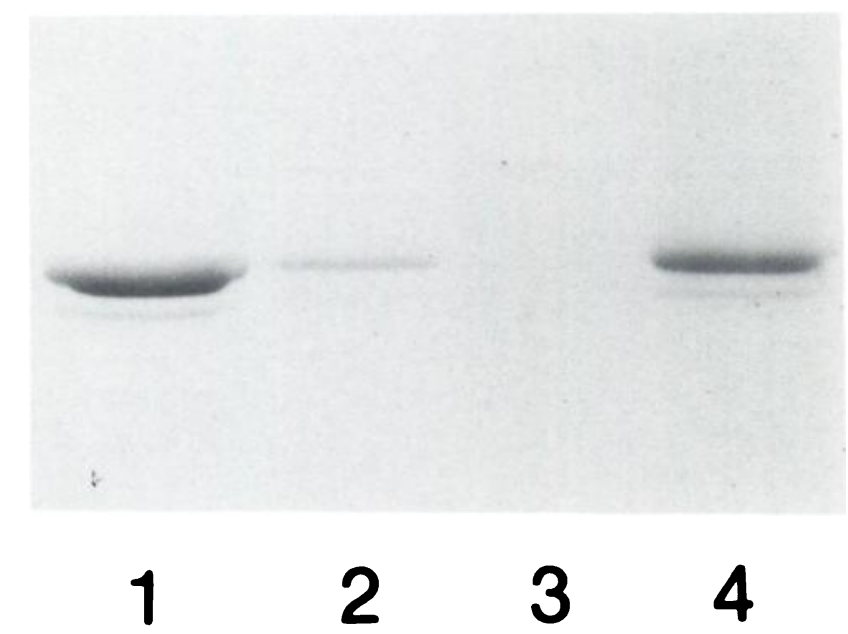

Fig. 3. Trifluoperazine does not prevent binding of annexin I to PS liposomes. Representative sodium dodecyl sulfate-polyacrylamide gel electrophoresis gel of supernatants (lanes 1 and 3) and 13,000 $\times g$ pellets (lanes 2 and 4) of reaction mixtures containing annexin I, PS liposomes, $312 \mu \mathrm{M}$ trifluoperazine, and either $1 \mathrm{mM}$ EGTA (lanes 1 and 2) or $6 \mathrm{mM}$ $\mathrm{Ca}^{2+}$ (lanes $\mathbf{3}$ and 4). Similar results were achieved with annexin II (data not shown).

not responsible for the co-sedimentation observed in the presence of $\mathrm{Ca}^{2+}$ and phospholipid.

\section{Inhibition by phenothiazines of neutrophil degranulation}

Treatment of neutrophils with streptolysin $O$ resulted in permeabilization of the plasma membrane, which allowed cytosolic constituents such as LDH to leak into the surrounding medium. Permeabilization of neutrophils with streptolysin $\mathrm{O}\left(75 \mathrm{U} / \mathrm{ml}, 10^{7}\right.$ cells, $\left.10 \mathrm{~min}\right)$ resulted in the leakage of $60.3 \pm 23.7 \%(n=10)$ of total LDH activity, whereas $95.6 \pm 6.2 \%(n=10)(P<.01)$ leaked out by 30

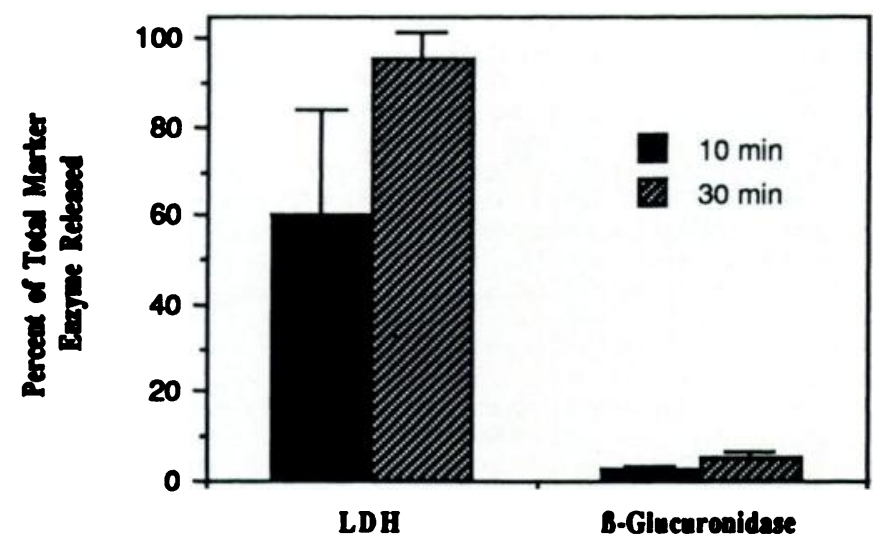

Fig. 4. Leakage of LDH (from cytosol) and B-glucuronidase (from granules) during permeabilization. Polymorphonuclear leukocytes $(5 \times$ $10^{6} / \mathrm{ml}$ ) were incubated for 10 or $30 \mathrm{~min}$ at $37^{\circ} \mathrm{C}$ with $75 \mathrm{U} / \mathrm{ml}$ streptolysin $\mathrm{O}$. After pelleting cells, supernatants were assayed for marker enzymes $(n=10)$. Results are expressed as mean \pm sD. Permeabolized polymorphonuclear leukocytes release $36.1 \pm 3.20 \%$ of their total $\beta$-glucuronidase in response to $300 \mu \mathrm{M} \mathrm{Ca}{ }^{2+}$ (mean \pm sEM). min. Despite the loss of cytosolic proteins, granule membranes remained relatively intact. Leakage of $\beta$-glucuronidase was $2.8 \pm 0.9 \%(n=10)$ and $5.1 \pm 1.7 \%(n=6)(P<$ .02 ) of the total at 10 and $30 \mathrm{~min}$ (Fig. 4), respectively. Moreover, neutrophils permeabilized with streptolysin O could be stimulated to release azurophil granule contents by the addition of micromolar concentrations of free ionized $\mathrm{Ca}^{2+}$. Increasing $\left[\mathrm{Ca}^{2+}\right]$ resulted in an increase in the $\beta$-glucuronidase activity released by permeabilized neutrophils (Fig. 5). The addition of trifluoperazine resulted in a concentration-dependent inhibition of the release of $\beta$-glucuronidase (Fig. 6). However, the percentage of inhibition of neutrophil degranulation was inversely related to the $\left[\mathrm{Ca}^{2+}\right]$ used to stimulate the cells. With increasing $\left[\mathrm{Ca}^{2+}\right]$, the percentage of inhibition by a given concentration of trifluoperazine decreased (Fig. 7).

\section{DISCUSSION}

The phenothiazines are known to inhibit exocytosis in a number of cellular systems. However, the mechanism(s) by which they do so remains unclear. Although they are potent inhibitors of calmodulin, we confirmed that phenothiazines also interact with members of the annexin family. Because the annexins have been implicated as potential membrane-fusing proteins mediating exocytosis, a clearer understanding of the interactions between the phenothiazines and the annexins may lead to a better understanding of exocytosis.

Previous studies have shown that promethazine and trifluoperazine inhibit annexin VII-mediated aggregation and fusion of phospholipid vesicles [12]. In the studies reported here we examined the effect of the phenothiazines on the two other annexins known to promote aggregation and fusion of phospholipid vesicles. We observed that, as with annexin VII, the phenothiazines inhibited annexin I- and annexin II-mediated aggregation of liposomes. The concentrations of phenothiazine required for this inhibition were higher than those reported for synexin. However, this difference may be related to the hydrophobic composition of the $\mathrm{NH}_{2}$-terminal of annexin VII in comparison to the $\mathrm{NH}_{2}$-terminal of annexin I or

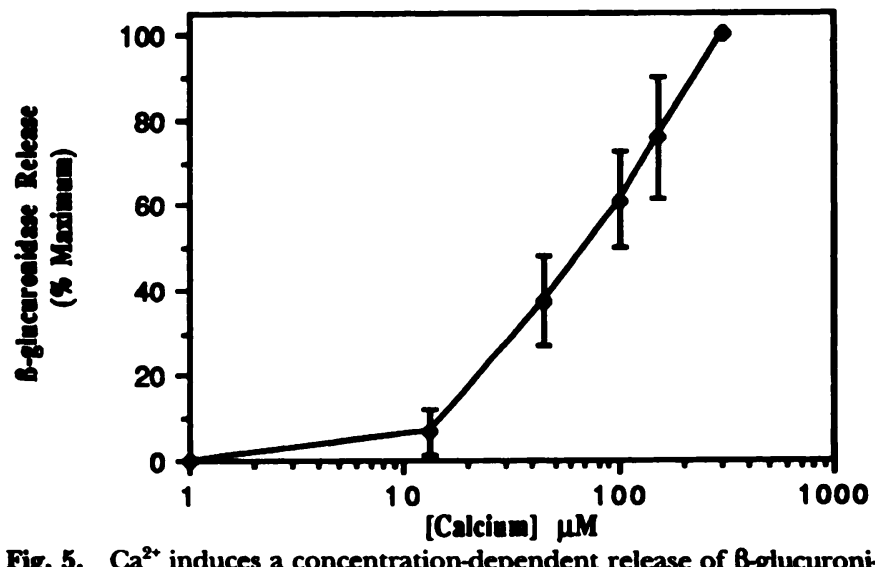

Fig. 5. $\mathrm{Ca}^{2+}$ induces a concentration-dependent release of $\beta$-glucuronidase from streptolysin $O$ permeabilized polymorphonuclear leukocytes. After a 10-min permeabilization (Fig. 4), cells were washed, resuspended in buffer $B_{;}$and incubated for $10 \mathrm{~min}$ at $37^{\circ} \mathrm{C}$ before stimulation with varying $\left[\mathrm{Ca}^{2+}\right]$. After an additional 10 -min incubation, the supernatants were collected and assayed for $\beta$-glucuronidase activity. All results are normalized against the release in response to $300 \mu \mathrm{M} \mathrm{Ca}^{2+}(n=10)$. Results are expressed as mean \pm sD. 
annexin II. Increased hydrophobicity correlates with increased inhibitory activity against calmodulin [21]. Furthermore, phenothiazine concentrations required for inhibition of annexin I- and annexin II-mediated liposome aggregation are within the range required for inhibition of exocytosis in both adrenal chromaffin cells and neutrophils [12-14].

The mechanism by which the phenothiazines inhibit annexin-mediated liposome aggregation is not dependent on diminished protein phospholipid binding. In the presence of the phenothiazines we observed normal binding of annexins to $\mathrm{PS}$ liposomes at $\mathrm{Ca}^{2+}$ concentrations at which no aggregation could be detected. The separation between the binding of an annexin to phospholipids and its ability to promote phospholipid vesicle aggregation has previously been established. Only three of the annexins have been shown to aggregate phospholipid vesicles, i.e., annexins I, II, and VII. Furthermore, the phospholipid binding site is thought to reside in the third repeat domain [22], whereas the ability of annexin I to promote aggregation has been localized to the first repeat [23]. Thus, the observed shift in the annexin-mediated, $\mathrm{Ca}^{2+}$-dependent aggregation curve to the right by the phenothiazines may represent protein-drug interactions involving the first repeat in annexins I and II.

Neutrophils permeabilized with streptolysin $O$ degranulate in response to micromolar concentrations of $\mathrm{Ca}^{2+}$. As with intact neutrophils [12], degranulation can be inhibited in permeabilized neutrophils by the phenothiazines. The characteristics of phenothiazine inhibition of degranulation resembles the inhibition observed with annexin-mediated liposome aggregation. There was an inverse relationship between $\left[\mathrm{Ca}^{2+}\right]$ and inhibition. This relationship is in striking contrast to the reported effect of the phenothiazines on calmodulin. The phenothiazines are known to bind directly to calmodulin in a $\mathrm{Ca}^{2+}$-dependent manner, with the optimal in vitro $\left[\mathrm{Ca}^{2+}\right]$ being $600 \mu \mathrm{M}$ [21]. Furthermore, previously examined calmodulin-dependent activities inhibited by the phenothiazines could not be salvaged through the addition of excess $\mathrm{Ca}^{2+}[24]$.

The studies reported here support the hypothesis that one or more of the annexins may help mediate the membrane-fusing events observed in neutrophil degranula-

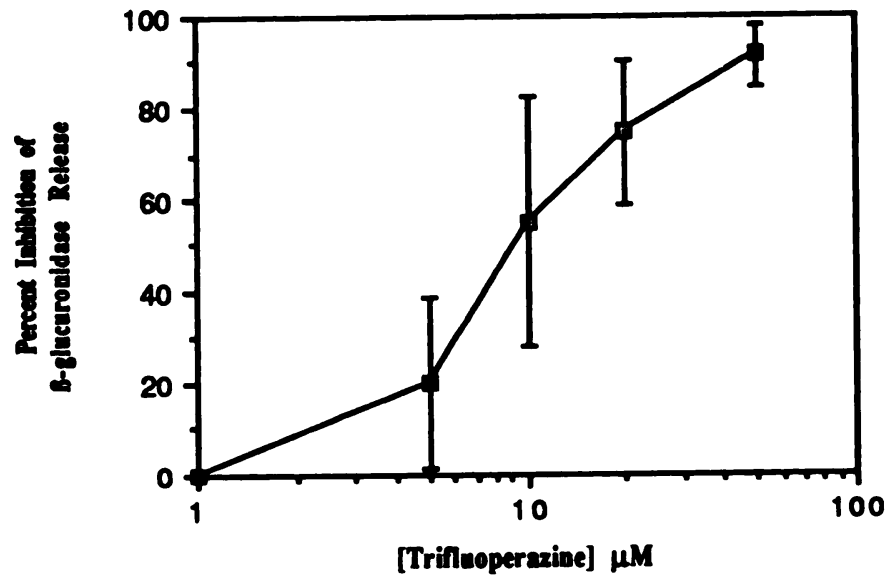

Fig. 6. Trifluoperazine exhibits a concentration-dependent inhibition of polymorphonuclear leukocyte degranulation. Conditions were the same as those described in Figure 5. Varying concentrations of trifluoperazine were added during the initial 10 -min incubation after permeabilization ( $n$ $=10) ;\left[\mathrm{Ca}^{2+}\right]=45 \mu \mathrm{M}$.

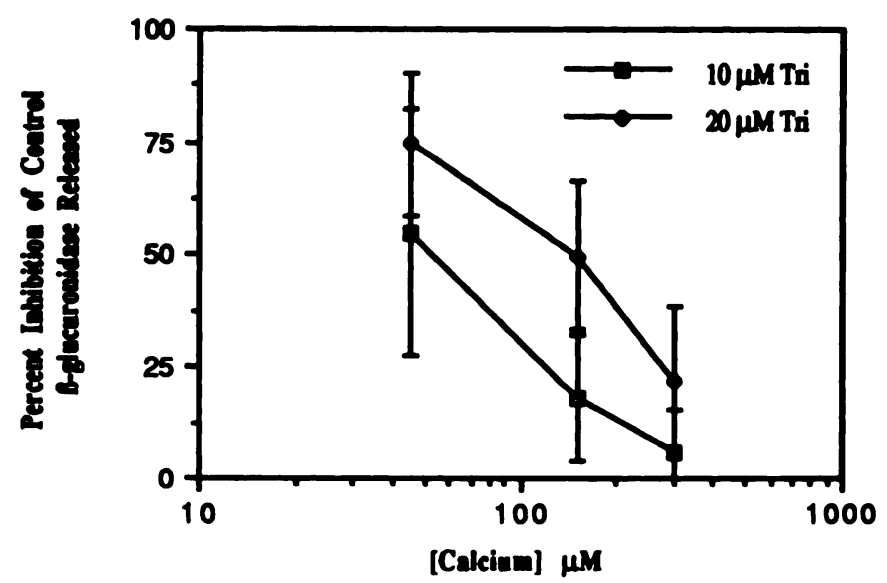

Fig. 7. $\mathrm{Ca}^{2+}$ reverses the inhibitory effect of trifluoperazine on polymorphonuclear leukocyte degranulation. Experiments were performed as described in Figure $5\left(n=10, P<.01,45 \mu \mathrm{M}\right.$ vs. $\left.300 \mu \mathrm{M} \mathrm{Ca}{ }^{2+}\right)$.

tion. The observed shift in the $\mathrm{Ca}^{2+}$ requirement of the annexin-mediated aggregation curve caused by the phenothiazines is sufficient to explain inhibition by the phenothiazines of neutrophil degranulation. Furthermore, in permeabilized neutrophils, where intracellular $\left[\mathrm{Ca}^{2+}\right]$ can be controlled, we observed a similar relationship between membrane-membrane contact, $\left[\mathrm{Ca}^{2+}\right]$, and phenothiazine concentration. A clearer understanding of the relationship between the annexins and the phenothiazines may yield further insight into the mechanism(s) of exocytosis.

\section{ACKNOWLEDGMENTS}

I would like to thank Dr. Ira Goldstein for critical review of this manuscript. This work was supported by a grant from the Robert Wood Johnson Foundation (grant no. 16239).

\section{REFERENCES}

1. Brugge, J.S. (1986) The $\mathrm{p} 35 / \mathrm{p} 36$ substrate of protein-tyrosine kinases inhibitors of phospholipase $A_{2}$. Cell 46, 149-150.

2. Burgoyne, R.D. (1988) Calpactin in exocytosis. Nature 331, 20.

3. Crompton, M.R., Moss, S.E., Crumpton, M.J. (1988) Diversity in the lipocortin/calpactin family. Cell 55, 1-3.

4. Blackwood, R.A., Ernst, J.D. (1990) Characterization of $\mathrm{Ca}^{2+}$-dependent phospholipid binding, vesicle aggregation and membrane fusion by annexins. Biochem. J. 266, 195-200.

5. Hong, K., Duzgunes, N., Ekerdt, R., Papahadjopoulos, D. (1982) Synexin facilitates fusion of specific phospholipid membranes at divalent cation concentrations found intracellularly. Proc. Nath. Acad. Sci. USA 79, 4642-4644.

6. Drust, D.S., Creutz, C.E. (1988) Aggregation of chromaffin granules by calpactin at micromolar levels of calcium. Nature 331, 88-91.

7. Creutz, C.E., Pazoles, C.J., Pollard, H.B. (1979) Self-association of synexin in the presence of calcium: correlation with synexin induced membrane fusion and examination of the structure of synexin aggregation. J. Biol. Chem. 254, 553-558.

8. Meers, P., Ernst, J.D., Hong, K., Dusgunes, N., Goldstein, I.M., Papahadjopoulous, D. (1987) Synexin-like protein from human polymorphonuclear leukocytes: identification and characterization of granule-aggregation and membrane-fusion.J. Biol. Chem. 262, 78507858.

9. Ernst, J.D., Hoye, E., Blackwood, R.A., Mock, T. (1991) Identification of a domain that mediates vesicle aggregation reveals functional diversity of annexin repeats. J. Biol. Chem. 266, 6670-6673.

10. Ali, S.M., Geisow, M.J., Burgoyne, R.D. (1989) A role for calpactin in calcium-dependent exocytosis in adrenal chromaffin cells. Nature 340, 313-315. 
11. Ali, S.M., Burgoyne, R.D. (1990) The stimulatory effect of calpactin (annexin II) on calcium-dependent exocytosis in chromaffin cells requirement for both the N-terminal and core domain of p36 and ATP. Cell. Signalling 2, 265-276.

12. Ernst, J.D., Meers, P., Hong, K., Duzgunes, N., Papahadjopoulos, D. Goldstein, I.M. (1986) Human polymorphonuclear leukocytes contain synexin a calcium-binding protein that mediates membrane fusion. Trans. Assoc. Am. Phys. 49, 58-66.

13. Ochs, D.L., Reed, P.W. (1981) Inhibition of neutrophil qxidative burst and degranulation in adrenal chromaffin cells. Biochem. Biophys. Res. Commun. 102, 958-962.

14. Pollard, H.B., Scott, J.H., Creutz, C.E. (1983) Inhibition of synexin activity and exocytosis from chromaffin cells by phenothiazines. Biochem. Biophys. Res. Commun. 113, 908-915.

15. Haigler, H.T., Schlaepfer, D.D., Burgess, W.H. (1987) Characterization of lipocortin I and an immulogically unrelated $33 \mathrm{kD}$ protein as epidermal growth factor receptor/kinase substrates and phospholipase $A_{2}$ inhibitors. J. Biol Chem. 262, 6921-6930.

16. Ernst, J.D., Hoye, E., Blackwood, R.A. (1989) Use of a novel stragedy for the preparation and characterization of an antipeptide capable of recognizing members of the annexin family. Biochem. Biophys. Res. Commun. 161, 959-964.

17. Bers, D.M. (1982) A simple method for the accurate determination of free [Ca] in Ca-EGTA solutions. Am. J. Physiol. 242, C404-C408.

18. Boyum, A. (1968) Isolation of mononuclear cells and granulocytes by one centrifugation, and of granulocytes by combining centrifugation and sedimentation at lg. Scand J. Clin. Invest. 21 (Suppl. 97), 77-89.

19. Wright, D.G., Bralove, D.A., Gallin, J.I. (1977) The differential mobilization of neutrophil granules: effect of phorbol myristate acetate and ionophore A23187. Am. J. Pathol. 87, 273-284.

20. Gallin, J.I., Fletcher, M.P., Seligmann, B.E., Hoffstein, S., Cehrs, K., Mounessa, N. (1982) Human neutrophil-specific granule deficiency: a model to assess the role of neutrophil-specific granules in the evolution of the inflammatory response. Blood 59, 1317-1329.

21. Weiss, B., Prozialeck, W., Cimino, M., Barnette, M.S., Wallace, T.L (1980) Pharmacological regulation of calmodulin. Ann. NY Acad. Sci 356, 319-345.

22. Meers, P. (1990) Location of tryptophan in membrane bound annexins. Biochemistry 29, 3325-3330.

23. Ernst, J.D., Hoye, E., Blackwood, R.A., Jaye, D. (1991) Purification and characterization of an abundant cytosolic protein from human neutrophils that promotes $\mathrm{Ca}^{2+}$-dependent aggregation of isolated specific granules. J. Clin. Invest. 85, 1065-1071.

24. Levin, R.M., Weiss, B. (1977) Binding of trifluoperazine to the calcium-dependent activator of cyclic nucleotide phosphodiesterase. Mol Pharmocol. 13, 690-697. 